\title{
Examination of the breast asymmetry associated with adolescent idiopathic scoliosis using surface topography methods
}

\author{
Alexandra Trovato ${ }^{1 *}$, Amin Komeili ${ }^{1}$, Lindsey Westover $^{2}$, Eric Parent ${ }^{3}$, Marc Moreau $^{4}$, Samer Adeeb ${ }^{1}$, \\ Esteban Sepúlveda ${ }^{1,5}$
}

From 10th International Conference on Conservative Management of Spinal Deformities - SOSORT 2013

Annual Meeting

Chicago, IL, USA. 8-11 May 2013

\section{Background}

Breast asymmetry in females is significantly more common in adolescent idiopathic scoliosis (AIS) than in nonscoliotic females [1]. Researchers and clinicians currently use the "Cobb angle" from radiographs as the standard assessment method for scoliosis. Since exposure to radiation has been shown to increase the risk of cancer [2], radiography is not the safest method of assessment. Unlike surface topography (ST), radiographic assessments do not measure cosmetic deformities associated with AIS, which is very important to patients and has a psychological impact on the quality of life [3].

\section{Purpose}

The objectives of this study were to observe the association between AIS and breast asymmetry using a 3-dimensional, markerless ST analysis technique, and to present a novel approach to analyze breast asymmetry that is associated with AIS.

\section{Methods}

Torso ST scans of 25 females with AIS (Cobb angle: $36.5^{\circ}$ $\pm 14.0^{\circ}$, curve types: Lenke $1,3,5$ and 6 ) were analyzed. The mean patient age was $15.4 \pm 1.3$ years (range: $13.5-$ 17.5). At the time of the scan, two patients were premenarchal and the remaining had experienced menarche $1.9 \pm 1.1$ years prior to the scan. The best plane of symmetry was found by mirroring the scan about the sagittal plane. The mirrored torso was fitted to the observed torso such that the average deviation between the torsos was minimized. The relative deviation between the mirrored and observed torso was measured and displayed as a deviation colour map (DCM). The DCMs were visually appraised, resulting in five types of breast asymmetry.

\section{Results}

Breast asymmetry was identified in all patients through a qualitative assessment. All had deviations exceeding $3 \mathrm{~mm}$ between sides. The patients were classified into five distinct groups based on their pattern of breast asymmetry.

\section{Conclusions and discussion}

All of the patients presented breast asymmetry that could be categorized into five groups. Future work includes the correlation of breast asymmetry classification to the type and severity of the scoliosis curve. This ST analysis technique provides a non-invasive and objective method to assess breast asymmetry in patients with AIS. Further work is required to test the reliability of this classification.

\footnotetext{
Authors' details

${ }^{1}$ Department of Civil and Environmental Engineering, University of Alberta, Edmonton, Alberta, USA. ${ }^{2}$ Department of Mechanical Engineering, University of Alberta, Edmonton, Alberta, USA. ${ }^{3}$ Department of Physical Therapy, University of Alberta, Edmonton, Alberta, USA. ${ }^{4}$ Department of Surgery, University of Alberta, Edmonton, Alberta, USA. ${ }^{5}$ Facultad de Minas, Universidad Nacional de Colombia, Colombia.
}

\footnotetext{
* Correspondence: atrovato@ualberta.ca

'Department of Civil and Environmental Engineering, University of Alberta,

Edmonton, Alberta, USA

Full list of author information is available at the end of the article
}

(c) 2013 Trovato et al; licensee BioMed Central Ltd. This is an Open Access article distributed under the terms of the Creative Commons Attribution License (http://creativecommons.org/licenses/by/2.0), which permits unrestricted use, distribution, and reproduction in any medium, provided the original work is properly cited. 


\section{References}

1. Normeli H, Sevastik JA, Ljung G, et al: The symmetry of the breasts in normal and scoliotic girls. Spine 1986, 11:749-752.

2. Levy AR, Goldberg MS, Mayo NE, Hanley JA, Poitras B: Reducing the lifetime risk of cancer from spinal radiographs among people with adolescent idiopathic scoliosis. Spine 1996, 21:1540-548.

3. Lai SM, Asher MA, Burton DC: Estimating SRS-22 quality of life measures with SF-36: Application in idiopathic scoliosis. Spine 2006, 31:473-8.

doi:10.1186/1748-7161-8-S2-039

Cite this article as: Trovato et al.: Examination of the breast asymmetry

associated with adolescent idiopathic scoliosis using surface

topography methods. Scoliosis 2013 8(Suppl 2):039.

\section{Submit your next manuscript to BioMed Central} and take full advantage of:

- Convenient online submission

- Thorough peer review

- No space constraints or color figure charges

- Immediate publication on acceptance

- Inclusion in PubMed, CAS, Scopus and Google Scholar

- Research which is freely available for redistribution

Submit your manuscript at www.biomedcentral.com/submit 